\title{
Some comments on aspects of the methodology for the measurement of stuttering
}

\author{
Lesley Caplan BA(Sp \& HTherapy) MA (Clin Psych) (Witwatersrand) \\ Tara, The H. Moross Centre, \\ Private Bag $X 7$ \\ Randburg, 2125
}

\begin{abstract}
The measurement of stuttering in a conversational context presents certain problems that are difficult to resolve despite a vast literature on the appraisal of stuttering behaviour. This view stems from problems encountered in a study designed to guage the effects of conflict, generated in a family context, on the stuttering behaviour of the child. Conflict was defined as a social process and was induced for the purpose of this study, by a standardised communication conflict situation. The results of the study were not significant, however, it was not concluded that stuttering and conflict are not related. Rather, there are difficulties in establishing this relationship. One of the difficulties concerns the measurement of stuttering. This paper is concerned with some aspects of the methodology for the measurement of stuttering that seem inadequate for research that has as its data, conversational interaction in a family context. Some alternative strategies are suggested.
\end{abstract}

\section{OPSOMMING}

Die diagnose van hakkel in 'n gespreksituasie lewer baie probleme op alhoewel daar baie literatuur oor die diagnose van hakkelgedrag bestaan. Hierdie probleem het na vore gekom in 'n studie wat ontwerp is om die effek van konflik in die gesins-konteks op die hakkelgedrag van die kind te evalueer. Konflik is as 'n sosiale proses gedefinieer en is toegepas by wyse van ' $n$ standaard kommunikatiewe konfliksituasie. Die resultate van die studie was nie betekenisvol nie, maar daar kan nie afgelei word dat hakkel en konflik nie verwant is nie. Daar is eerder struikelblokke om die verwantskap te evalueer. Een so 'n struikelblok is dat die meting van hakkelgedrag problematies is. Hierdie artikel lig metingsmetodes vir navorsing uit wat onvanpas is vir die verwerking van data verkry uit gespreksinteraksie in 'n gesinskonteks. Altermatiewe metodes geniet aandag.

The quality of most research on stuttering behaviour is disappointing and despite attempts to enhance the standard of inquiry and a plea for greater empirical sufficiency, ${ }^{22}$ many deficiencies are apparent. Little, if any, attention has been given in recent years to measurement conventions such as severity ratings and frequency counts, which constitute the bedrock of assessment of stuttering, or to the nature and size of the speech sample for this procedure. ${ }^{20}$ In the main, reading passages and short samples of self-formulated speech have been the data for appraisal. It seems that certain assumptions that were made in the early years to permit "an operationally meaningful appraisal of stuttering"s have been accepted and utilised with little questioning of their 'truth'.

In the light of this, the measurement of stuttering in a conversational context presents certain problems that are difficult to resolve despite a vast literature on the methodology for the assessment of stuttering. It may well be that the measurement strategies that have been developed, mask information about stuttering, particularly when applied to conversational data.

This view stems from difficulties encountered in a study on the relationship between conflict in the family and stuttering xehaviour.

A brief synopsis of the study follows.

\section{METHODOLOGY}

The experimental sample consisted of 20 families, each comprising biological mother and father and their stuttering child.

The stuttering children were considered to qualify as Track 1 stutterers, ${ }^{21}$ were all boys ranging in age from 8 to 12 years, coping adequately at school and from middle class, Englishspeaking South African backgrounds.

The standardised communication conflict situation devised by Blakar ${ }^{3}$ was used to generate conflict and to elicit the stuttering behaviour of the child in the family context.

Briefly, the task comprises a map of a complex network of streets through a city centre, a copy of which is given to each of two (or more) participants. One of the participants has two routes marked on the map; a short simple route and a longer more complicated one. The other participant/s has/have a map on which no routes are marked. The object of the exercise is for the participant/s with the routes to explain to the other/s how to get through the city to certain endpoints via the predetermined routes. The short simple route permits a baseline measure of behaviour, in this instance stuttering, while the longer route, by virtue of a small discrepancy between the maps is impossible to complete successfully, so generating conflictual interaction. 
The design accommodates a parent-child constellation (a triad) and permits the ascribing of roles to the participants as either 'explainers' or 'followers'. Whatever the role assigned however, the standardised communication conflict situation constitutes a complex linguistic task demanding flexibility and ensuring a high degree of communicative responsibility for all the participants. It is intrinsically a highly propositional task, which means that language is being used intentionally and intellectually to convey meaning and information. ${ }^{5,8}$ Such a task demands precise accurate verbal communication. This limits the ability of the participants to circumlocute, and so in the case of the stuttering child avoid those words that could precipitate dysfluency.

The influence of conflict in the context of the family, on stuttering behaviour of the children, was examined by rating the severity of stuttering and by frequency counts of all dysfluencies as well as frequency of repetitions and prolongations the so-called "core features" of stuttering. ${ }^{21}$ A 7-point rating scale was used for the severity of stuttering, while frequency was determined by making verbatim transcripts of the data, analysing the dysfluencies using the Iowa Categories of Dysfluency ${ }^{11,}{ }^{12}$ and computing ratios in relation to the total verbal output.

As the standardised communication conflict situation generates conversational interaction, the data for the measurement of stuttering of the child in each family triad comprises a sample of discourse of variable length.

There is limited experimentation directed towards ascertaining what constitutes an adequate speech sample representative of the stutterer's speech, and clearly contextual or situational aspects deserve consideration as well as the length of the sample for assessment.

The tradition in research on stuttering has been to use oral reading material as the data, but with the recognition that this is not representative of the communication behaviour of the stutterer, various 'spontaneous speech' tasks have been introduced. ${ }^{12}$ These however, tend to elicit monologues rather than conversational discourse. In general a 3-minute sample of such speech has been considered adequate. However, the preferred method has remained the use of reading material, dictated by the experimental control afforded over certain linguistic parameter's considered relevant to stuttering. The paucity of work on so-called spontaneous speech and even less so on speech in a conversational context, is not surprising in the face of difficulties in holding constant, not only the relevant dimensions of the speech output, ${ }^{16,17}$ but in determining which of a gamut of factors both incidental and manipulated, may be operating.

For the purpose of the present study, the conversational data was segmented into observational periods of 5 minutes and for each family two, and in some instances, three such samples were used for the analysis of stuttering behaviour in the face of conflict in the family. For the baseline measures of stuttering the entire interaction on the short simple route of the task
was used. :

The design of the study was therefore, of the pretest-posttest type. Analyses of Covariance were performed to determine the statistical significance of the findings.

Die Suid-Afrikaanse Tydskrif vir Kommunikasieafwykings, Vol. 30,1983

\section{RESULTS}

The results of the study were not significant, however, it was not concluded that conflict and stuttering are not related. Rather there are difficulties in establishing this relationship. One of the difficulties concerns the definition and measurement of stuttering. The complexities of the definitional problem will not be considered here. While the current study followed accepted conventions for appraisal, what does differ fundamentally from 'standard' procedures is the manner in which the speech sample was elicited. It seems that the somewhat global measures used in this study, and most often in research on stuttering, may be inadequate for assessing dysfluency in a verbal interchange in a family context.

\section{A more detailed consideration of these issues follows.}

\section{DISCUSSION}

Clearly the conversational discourse elicited by the standardised communication conflict situation is a far cry from the reading material and 'monologues' of self-formulated speech traditionally used in clinical and research settings with stutterers. Conversational discourse involves an individual's ability to use language not only in terms of its grammatical structure, but also as regards its appropriateness in relation to a variety of different contexts. ${ }^{10}$ Conversation taxes capacities to integrate "linguistic, cognitive and social rules", ${ }^{14}$ so that communication is realized, not only through the verbal repertoire, but through an awareness of a "complex matrix of referential codes", ${ }^{18}$ some linguistic and paralinguistic, and some of which are socioculturally determined. With this in mind, it is clear that conversational speech in a communication context is a network of multiple factors, individual and social, and any analysis of such discourse must take cognisance of them.

A parameter of discourse that can be used to illustrate the complexity of such an approach concerns features like the postponements, hesitations and retrials that often accompany attempts to formulate and transmit meaningful information. The absence of criteria to define fluency remains a stumbling block in any consideration of dysfluency ${ }^{7}$ and given conversational discourse as the data for an investigation of stuttering behaviour, even the apparently simple procedure of counting the number of words that constitute the total verbal output of an individual poses a major problem. Decisions have to be made as to whether words form an integral part of the meaningful context ${ }^{12}$ or not and this is not a clear cut task, given the revisions and changes that characterise conversational speech.

In considering the measurement of stuttering once again, it could be argued that frequency counts, while constituting a substantial component of the degree of stuttering, are not sufficient. ${ }^{2}$ Other factors, such as the duration of stuttering moments and the tension and struggle behaviour accompanying speech, also contribute to assessment. These features do manifest in the overall tempo of speech and a consideration of the rate of utterance is important in a comprehensive appraisal of stuttering behaviour. As regards the rate of utterance Dalton \& Hardcastle ${ }^{7}$ recommend a measure of the number of syllables uttered in each second in a sequence of speech for the rate of utterance. There are, of course, difficulties in measuring such short segments accurately with a stop watch. Spec- 
trographically, this may be possible, but a certain expertise and skill is required in using the equipment and analysing the results. More specifically with reference to the present study, it becomes difficult to find uninterrupted sequences of speech of sufficient duration in a conversational interchange to permit accurate timing without expensive electronic aids.

In summary, stuttering is clearly a variable disorder, and the moment of stuttering is a non-unitary combination of a variety of behaviours. ${ }^{6}$ That some undefined incident evaluated as stuttering has been considered to occur, remains the hallmark of measurement in clinical and experimental work in the field. ${ }^{6}$ The problems in definition and the inextricably related difficulties in delineating operations to measure stuttering as well as the reliability of these measures are not insubstantial. In the light of such complexity and the absence of clearlydefined parameters, recourse to 'consistency' has been the only option in the measurement of stuttering. Certain rules are specified to ensure this consistency and so permit some modicum of control. ${ }^{12}$

It is the present writer's contention however, that these measures are not necessarily capturing the problem behaviour and that given the intrinsic fluctuant, almost mercurial nature of stuttering, frequency counts and severity ratings are too global. It seems that a single rating of severity on a 3-minute sample of speech, or frequency counts of moments of stuttering expressed as a ratio of the total verbal output, yield measures of 'mean' stuttering. Little can be said on the basis of these and most of the contemporary measurement conventions, about change in stuttering behaviour.

In the light of the variability of stuttering, a phenomenon repeatedly noted but subjected to surprisingly little systematic research,' attention to the 'extremities' of stuttering behaviour and attempts to track changes moment by moment could represent a more refined way of measuring stuttering than the averaging out of stuttering behaviour as a function of the measurement procedures. It may be the very imposition of consistency on the essential variability of stuttering behaviour that may be masking our knowledge of the disorder.

Having presented a critique of some aspects of the methodology of the measurement of stuttering, it remains to propose some alternative strategies and some rudimentary ideas.

It seems that the criticism of research on stuttering for "an insufficiency of empiricism"22 has in fact been perceived and the plea for a more rigorous methodology has been headed by some investigators.

\section{A consideration of some of this work follows.}

There seems to be a need not only for meticulous research into the phenomenology ${ }^{21}$ or overt manifestations of stuttering behaviour, ${ }^{15}$ but as already suggested, to track stuttering and relate it, moment by moment, to both language use and its social context. ${ }^{24}$ The conceptual framework for the study of communication by Blakar ${ }^{4}$ and his associates, and the model for and understanding of stuttering by Wertheim, ${ }^{23}$ seem to provide some guidelines for this endeavour. An attempt will be made to integrate some recent research in stuttering with these views.
The writings of Kaasin and Bjerkan ${ }^{13}$ reveal both a recognition of the subtle interplay between the individual and the multiplicity of situational and social variants in the act of communication $^{4}$ and some attempt to encompass these aspects in research. They point out that two issues have been the concern of research on situational variability and stuttering. These are first, the actual situations in which speech takes pläce, and second, the locus of stuttering in the speech sequence with actual words being attributed with properties that could precipitate the moment of stuttering. Berkjan ${ }^{13}$ coined the concept "critical word" to characterise "the relationship between a word and a situation" so that it is not the word itself that carries the complex of precipitating factors but the word "with reference to the dialogue". Similarly, the work of Wertheim $^{23,24,25}$ has relevance. Her exposition of the learning of word-meaning and its importance in interpersonal relationships, particularly in the context of the family, not only complements the concept of critical words, ${ }^{13}$ but extends this to permit a definition of critical situations or "sensitive 'stutterogenic' areas for a given individual". ${ }^{24}$

Given this, recourse to the work of Blakar ${ }^{4}$ and his associates reveals an approach to the analysis of verbal interaction, on an utterance level and a categorisation system anchored in communication theory and social-developmental psychology, that would seem to facilitate the kind of research mentioned above. Concepts such as attribution from social psychology, or egocentricism, one of the contributions to developmental psychology for which Piaget is renowned, have been productively used in research on psychopathology and deviant behaviour. Issues such as who attributes the difficulty, in what way, to what aspect of the situation, or to whom and how the other responds, are all considered. ${ }^{4}$ Using the standardised communication conflict situation already described and the conversational data elicited by the task, an utterance-byutterance analysis of the interaction thus generated becomes possible. Every instance "of an explicit attempt at attributing the experienced communication difficulty"s can be identified and categorised in terms, for example, of who, what, how, and the response evoked. This could be accompanied by a concurrent and linking analysis of each moment of stuttering. The compatibility of this with the work of Kaasin and Bjerkan ${ }^{13}$ is evident.

\section{CONCLUSION}

It seems that there are deficits in stuttering research that have become "perennials" 19 and despite pleas for greater empiricism 22 and an unified effort to enhance the quality of stuttering research, ${ }^{20}$ little progress has been made. It is clear that despite stuttering being deemed "an impediment in social living"2l the model underlying research efforts seems to have been that of individual psychology. As Blakar" puts it "this model is well suited to understanding the individual as language-user in various aspects. But the model is totally inadequate with regard to the social and situational aspects of communication and even hinders questions to be posed". Given the subtle interplay between the individual and the multiplicity of situational and social variants in the act of communication, it seems that a single rating of severity of stuttering on a 5-minute sample of conversation or frequency counts of moments of stuttering expressed as a ratio of the total verbal 
output are too global and inclusive. The result is a measure of 'mean' stuttering. In the light of the variability of stuttering, it seems that much of the essence of stuttering is being lost.

It is clear that the present paper has merely touched on the issues involved. Research designs remain simplistic, subject populations are usually small and comprise college and university students with little attention to children. Additional$l y$, the controversy as to whether suttering frequency data constitute interval data or not ${ }^{20}$ and the assumptions of linearity of regression and homogeneity of variance, particularly in the case of self-formulated speech, deserve consideration. ${ }^{17}$ Much remains to be done in research and in synthesising the wealth of data on stuttering. Only with this effort and improvements in the quality of research in stuttering can some contribution to the elusive solution to the "riddle" of stuttering ${ }^{21}$ be made.

\section{ACKNOWLEDGEMENTS}

Sincere thanks are expressed to Prof. G. Straker, Head of the Applied Division of the School of Psychology, University of the Witwatersrand, Johannesburg, for her supervision of the study from which this paper is drawn.

\section{REFERENCES}

1. Andrews, G., \& Harvey, R. (1981): Regression to the Mean in Pretreatment Measures of Stuttering. Journal of Speech and Hearing Disorders, 2, 204-207.

2. Aron, M. L. (1967): The Relationships between Measurements of Stuttering Behaviour. Joumal of the South African Logopedic Society. 14, 15-34.

3. Blakar, R. M. (1973): An Experiential Method for inquiring into Communication. European Joumal of Social Psychology, 3, 415-425.

4. Blakar, R. M. (1980): Studies of Familial Communication and Psychopathology: A Social-Developmental Approach to Deviant Behaviour. Universitetsforlaget, Oslo.

5. Bloodstein, O. (1969): A Handbook on Stuttering. National Easter Seal Society for Crippled Children and
Adults, Chicago.

6. Brutten, G. J. (1975): Stuttering: Topography, Assessment and Behavior-Change Strategies in Stuttering: A Second Symposium. Eisenson, J. (Ed.) Harper \& Row, New York.

7. Dalton, P. \& Hardcastle, W. J. (1977): Disorders of Fluency and their Effects on Communication. Edward Arnold London.

8. Eisonson, J. (1975): Stuttering as Perseverative Behavior in Stuttering A Second Symposium. Eisenson, J. (Ed.)

Harper \& Row, New York

9. Hultberg, M., Alve, S., \& Blakar, R. M. (1980): Patterns of Attribution of Communication Difficulties in Couples having a 'Schizophrenic', a 'Borderline' or' 'Normal' off- spring in Studies of Familial Communication and Psychopathology: A Social-Developmental Approach to Deviant Behaviour. Blakar, R. M. (Ed.) UniverSorlo.

10. Hymes, D. H. (1972): On Communicative Competence in Sociolinguistics: Selected Readings. Pride, J. B. \& Holmes, J. (Eds.) Penguin Education, London.

11. Johnson, W. (1961): Measurements of Oral Reading and Speaking Rate and Disfluency of Adult Male and Female Stutterers and Non-Stutterers. Joumal of Speech and Hearing Disorders Monograph, 7, 1-20.

12. Johnson, W., Darley, F. L., \& Spriestersbach, D. C. (1963): Diagnostic Methods in Speech Pathology. Harper \& Row, New York

13. Kaasin, K., \& Bjerkan, B. (1982): Critical Words and the Locus of Stuttering in Speech. Journal of Fluency

14. Kagan, A. (1977) 433-446.

. Kagan, A. (1977): Aspects of Cohesion and Tense in the Discourse of the Older Child. Unpublished Undergraduate Research Project, University of the Witwatersrand, Johannesburg.

15. Marks Wahlhaus, M. (1979): Judges Agreement on Auditory and Visual Aspects of Stuttering. The South African Journal of Communication Disorders, 26, 3-18.

16. Minifie, F. D. \& Cooker, H. S. (1964): A Disfluency Index. Journal of Speech and Hearing Disorders, 29 189-192.

17. Moore, W. E. (1954): Relations of Stuttering in Spontaneous Speech to Speech Content and Adaptation. Journal of Speech and Hearing Disorders, 19, 208-216.

18. Muma, J. R. (1975): The Communication Game: Dump and Play. Journal of Speech and Hearing Disorders, 40,
296-307.

19. Rieber, R. W., \& Wollock, J. (1977): The historical roots of the theory and therapy of stuttering. Journal of Communication Disorders, 10, 3-24.

20. Sommers, R. K. Bobkoff-Leventhal, K., Applegate, J. A. \& Square, P. A. (1979): A Critical Review of a Decade of Stuttering Research. Journal of Fluency Disorders, 4,

21. Van Riper, C. (1971): The Nature of Stuttering. PrenticeHall, Englewood Cliffs, New Jersey.

22. Webster, R. L. (1977): Concept and Theory in Stuttering: An insufficiency of Empiricism. Journal of Communication Disorders, 10, 65-71.

23. Wertheim, E. S. (1972): A Bio-Adaptive Theory of Stuttering. I. British Journal of Medical Psychology, 45,
283-295.

24. Wertheim, E. S. (1972): A New Approach to the Classification and Measurement of Stuttering. Journal of Speech and Hearing Disorders, 37, 242-251.

25. Wertheim, E. S. (1972): What is in a Word? British Journal of Medical Psychology, 45, 35-43. 